\title{
Teaching Color Words in CSL: A Teaching Note for Informal CSL Learners in New Zealand
}

\author{
BAO Chun-rong \\ The University of Auckland, New Zealand
}

\begin{abstract}
While a plethora of research have examined Chinese vocabulary containing "colors", there is a paucity of research on teaching color words to people learning Chinese as a second/foreign language (CSL). Such a lacuna becomes prominent in many occasions when color words make CSL learners confused and embarrassed. If CSL learners lack the awareness of color culture, they might be trapped in the perplexing meanings of these words, especially in non-native Chinese-speaking contexts. In order to fill in this gap, this study reports on a two-year CSL program in New Zealand (NZ), aiming to provide some useful implications for vocabulary pedagogical suggestions for teaching color words.

Keywords: Chinese vocabulary, CSL, New Zealand
\end{abstract}

\section{Introduction}

While a plethora of research have examined Chinese vocabulary containing "colors" (e.g., Luo, 2004; Qian, 2006), there is a paucity of research on teaching color words to people learning Chinese as a second/foreign language (CSL). Such a lacuna becomes prominent in many occasions when color words make CSL learners confused and embarrassed. In addition to literal meaning, some Chinese color words also have special Chinese cultural implications, such as 红娘 (matchmaker) and 绿帽子 (green hat, which is used to describe a man whose wife has cuckolded him). If CSL learners lack the awareness of color culture, they might be trapped in the perplexing meanings of these words, especially in non-native Chinese-speaking contexts. In order to fill in this gap, this study reports on a CSL program in NZ, aiming to provide some useful implications for vocabulary pedagogical suggestions (Nation, 2001) for color words teaching in TCSOL. This study followed "seeking and identifying and effective vocabulary instruction approach are important goals of Chinese pedagogical studies" (Shen, 2010, p. 486). Two key questions guided the study: What strategies did the teacher adopt in teaching color words? How did the learning influence CSL learners?

\section{This Study}

The program reported in this study was embedded in an informal CSL course in NZ. This program aimed to help informal CSL learners to have a general knowledge of Mandarin Chinese and Chinese culture. Eight students from three local families (Family One: mother, daughter, and son; Family Two: mother, father, and

BAO Chun-rong, Ph.D. Candidate, Faculty of Education and Social Work, The University of Auckland, New Zealand. 
daughter; Family Three: father and son) weekly attended this program over two years (one hour per week). Considering both adults and children attended the same class, the teaching program must be based on family activities. As the teacher in this program, the researcher took her teaching plans, memos, diaries, and records of weekly communication with students as the data. All the data were transcribed and analyzed by the researcher.

\section{The First Period: The Elementary Level (0-6 months)}

\section{Teacher's Strategies: Noticing and Retrieving}

The initial task for elementary learners was to master the literal meanings, such as 红 (red), and 蓝 (blue), and to enhance retention of the basic meanings. Following Boers, Eyckmans, and Stengers's (2007) Dual Coding Theory, which calls up "a mental image of a concrete scene which can be stored in memory alongside the verbal form" (p. 43), this section took notice and retrieval as two basic strategies (Nation, 2001). The former emphasizes "seeing the word as an item to be learned" (Nation, 2001, p. 221); the latter involves "recall of previously met items" (Nation, 2001, p. 221). As such, orally and visually repeating the words by showing color or word cards might be good options (Nation, 2001). In addition, the teacher also introduced the color words used as adjectives, and helped the students to describe concrete items, such as 红衣服 (red clothes), 红裤子 (red pants), and the like. In the following classes, students were encouraged to retrieve these color words through listening, speaking, reading, and writing (Nation, 2001) at times.

\section{Students' Reflection}

In this period, with the visible concrete items in the class, all of the students had no problem with color words. These parents shared that they also practiced after class, tried to identify the colors with their limited Chinese words, and looked up some other unknown color words in dictionaries autonomously.

\section{The Second Period: The Intermediate Level (7-12 months)}

\section{Teacher's Strategies: Incidental Learning and Intentional Learning}

For intermediate learners, both incidental learning and intentional learning (Nation, 2001) were applied, because no more than $25 \%$ of language items were from direct study (Nation, 2001). Learners then had more capabilities of learning vocabulary incidentally from reading or listening (Nation, 2001), but they also encountered some words at times, and could not infer the meanings literally, such as 红娘 (matchmaker), even if they knew the meaning of every Chinese character, such as 红 (red) and 娘 (mother). In effect, these words are not completely arbitrary; instead, some of them have figurative usage which offers students opportunities to promote insightful learning (Boers, Eyckmans, \& Stengers, 2007).

Theoretically, once the learners have mastered at least $95 \%$ of the running words, they might be capable of guessing the unknown words (Nation, 2001). For example, when explaining “红红火火”, the teacher referred to “祝你的生意红红火火” as the context. Since the students had learnt the meanings of “祝”, “你的”, “生意” were “may/wish" "your” "business" respectively, they could infer that “红红火火” was good wishes for " business”, such as to be prosperous, blooming or flourish.

However, "learners must be given credit for guesses that are not $100 \%$ correct but which make a small but positive contribution to knowledge of the meaning of the word" (Nation, 2001, p. 234). In such case, the instant, direct, and appropriate explanation to cultures not only encouraged intentional learning, but also aroused the 
learners' interest. Still take “红红火火” as an example, “红” originates from the color of sun. In ancient times, people admired the sun, so people considered its color as the symbol of success or happiness (Qian, 2006). Following such incidental and intentional learning, most learners were able to infer the meanings of "红人 (popular person)” “红运 (good luck)”, etc. (Luo, 2004).

\section{Students' Reflection}

In this period, students started to notice collocations containing color words. Whenever they encountered such collocations, they tended to ask whether these color words had special meanings. For example, having learnt “红人 (popular person)”, they asked the meanings of “黑人 (black person)” and “白人 (white person)”. While their curiosity of color words was initiated, they became more cautious when they spoke Chinese than the first period. As the mother of Family One noted, "I am always wondering whether what I said was correct or not...luckily, my Chinese friends were very nice...they didn't mind..." such self-doubt was also evident in the other two families, especially the adults, “...but I enjoy the adventure...” said the father of Family Two.

\section{The Third Period: The Advanced Level (The Second Year)}

\section{Teacher's Strategies: Culture Instruction and Learning Tools}

In addition to such learning strategies in the first two periods as word cards, noticing, retrieving, and guessing from the context, dictionary was also recommended (Nation, 2001). A proper dictionary like Grand Dictionary of Chinese Language ( $\mathrm{Ci} \mathrm{Hai}$ ), a source of information for etymology, assists learners to go beyond "blind" rote-learning (Boers et al., 2007). In addition, cultures were instructed via a variety of techniques, such as Chinese literature and Chinese movies.

\section{Students' Reflection}

The instruction of cultures not only widened learners' understanding of the color words, but also enhanced the awareness of color culture. For example, learners noticed in movies, “红蜡烛 (red candle)”, “红双喜 (red double “xi”-A Chinese character meaning happiness)”, “红盖头 (red head cover)”, “红喜帖 (red invitation card)”, and “红包 (red packet containing money as a gift)" in traditional Chinese weddings; in the movie 白毛 女 (The White-haired Girl), YANG Bai-lao bought a “红头绳 (red hair band)” for his daughter Xi'er as a new-year gift. All of these scenes in movies stressed that “红” was used in auspicious or happy occasions. At the end of the program, all the three families acknowledged that they were more interested in Chinese, in both the language and the culture. "...I have realized that learning Chinese is tricky, but it's interesting..." said the father of Family Three.

\section{Discussion and Conclusion}

This report has introduced some pedagogical suggestions for color words teaching in a CSL program in NZ lasting for two years, covering elementary, intermediate, and advanced levels. Within each period, the problems students encountered, the potential solutions the teacher did or might adopt, and students' reflection after class have been instructed. The program also revealed that the children participated in the activities actively, and were more interested in speaking, whereas their parents played the role of tutors and had stronger willingness to have a better understanding of cultures backing up the language. 
Through the lens of color words teaching, it can be detected that cultural misunderstandings are prominent in CSL, and even worse, became the barrier in CSL learning, therefore the instruction of cultural context should become one of the cores of CSL curriculum.

\section{References}

Boers, F., Eyckmans, J., \& Stengers, H. (2007). Presenting figurative idioms with a touch of etymology: More than mere mnemonics? Language Teaching Research, 11(1), 43-62.

Luo, F. (2004). Han yu se cai ci de wen hua shen shi (On Chinese cultural color meanings) (1st ed.). Shanghai, China: Lexicographical Publishing House.

Nation, I. S. P. (2001). Learning vocabulary in another language. Cambridge, UK: Cambridge University Press.

Qian, Y. (2006). Xian dai Han yu ci hui jiang yi (Handbook of modern Chinese lexicology) (1st ed.). Beijing, China: Peking University Press.

Shen, H. H. (2010). Imagery and verbal coding approaches in Chinese vocabulary instruction. Language Teaching Research, 14(4), 485-499. 